\author{
Al-wardah: Jurnal Kajian Perempuan, Gender dan Agama \\ Volume : 13 No 1. Edisi Juni 2019 \\ ISSN: 1907-2740, E-ISSN: 2613-9367 \\ DOI: $10.46339 /$ al-wardah.v13i1.162
}

\title{
Penyalahgunaan \\ Narkoba Pada Anak -Anak Dibawah Umur Dan Penanggulangannya
}

\author{
Fitri Rizki Amelia \\ Apoteker.Ternate.Indonesia \\ fitri.rizki@gmail.com
}

\begin{abstract}
Abstrak
Maraknya penyalahgunaan barang haram (narkoba) akhir-akhir ini menjadi isu yang sangat mengkhawatirkan di Indonesia. Dari fakta yang dapat disaksikan baik melalui media cetak maupun elektronik, Narkoba tersebut telah merebak kemana-mana terutama diantara remaja yang sangat diharapkan menjadi generasi penerus bangsa dalam membangun negara di masa mendatang. Narkoba dapat membahayakan kehidupan manusia, jika dikonsumsi dengan cara yang tidak tepat, bahkan dapat menyebabkan kematian. Narkoba mempunyai dampak negatif yang sangat luas; baik secara fisik, psikis, ekonomi, sosial budaya hankam, dan lain sebagainya. Banyak cara digunakan agar pemakai narkoba dapat normal dan pulih kembali seperti biasanya.Sehingga kepada pemakai / pengedar dalam ketentuan hukum pidana nasional diberikan sanksi yang berat. Metode penelitian adalah studi kepustakaan, hasilnya adalah kasus penyalahgunaan narkoba mengalami peningkatan sangat tajam karena belum ada standarisasi sistem pencatatan dan pelaporan penyalahgunaan narkoba.
\end{abstract}

\section{Kata Kunci : Narkoba dan Anak-anak}

\begin{abstract}
Abstrac
he rise of abuse of illicit goods (drugs) lately has become a very worrying issue in Indonesia. From the facts that can be witnessed both through print and electronic media, the drug has spread everywhere, especially among teenagers who are expected to become the next generation of the nation in developing the country in the future. Drugs can endanger human life, if consumed improperly, it can even cause death. Drugs have a very broad negative impact; both physically, psychologically, economically, socio-cultural defense and security, and so forth. Many methods are used so that drug users can be normal and recover as usual. So that users / dealers in the provisions of national criminal law are given severe sanctions. The research method is a literature study, the result is a
\end{abstract}


case of drug abuse has increased very sharply because there is no standardization system for recording and reporting drug abuse.

Keywords: Drugs and Children

\section{A. Pendahuluan}

Sudah bukan rahasia lagi, bahwa penyalahgunaan narkoba atau narkotik dan obatobat terlarang di tanah air kita Indonesia, kini telah mencapai proporsi yang semakin meresahkan. Sehingga sejak pertengahan tahun 1998 yang lalu, dalam rangka pencegahan dan pemberantasannya, para aparat keamanan negara pun telah lebih meningkatkan kegiatan untuk terus mengadakan berbagai macam razia atau operasi, sebab penyebaran narkoba tidak saja telah merata, tetapi benar-benar semakin merata 'tidak pandang bulu'. Sasarannya tidak hanya remaja dan dewasa muda di kota-kota besar, tetapi telah menyusup ke pelosok-pelosok desa. Bahkan yang lebih meresahkan karena mereka (para pecandu narkoba) telah banyak mempengaruhi anak-anak di bawah umur dan bukan lagi anak-anak SMP, tetapi SD.

Maraknya penyalahgunaan barang haram (narkoba) akhir-akhir ini menjadi isu yang sangat mengkhawatirkan di Indonesia. Dari fakta yang dapat disaksikan hampir setiap hari baik melalui media cetak maupun elektronik, barang haram tersebut telah merebak kemana-mana tanpa pandang bulu, terutama di antara remaja yang sangat diharapkan menjadi generasi penerus bangsa dalam membangun negara di masa mendatang. Penyalahgunaan narkotika telah menyusup didalam lingkungan pendidikan, mulai dari kampus, SMU, sampaikepada murid-murid sekolah dasar, bahkan dikalangan artis, eksekutif, dan pengusaha.Penyalahgunaan narkoba dapat merusak perkembangan jiwa generasi muda baik bagi sipengguna maupun orang lain.Narkoba sebagai zat yang sangat diperlukan untukpengobatan dalam pelayanan kesehatan seringkali disalahgunakan tidak sesuai dengan standar pengobatan dan jika disertai peredaran narkoba secara gelap akan menimbulkan akibat yangsangat merugikan perorangan ataupun masyarakat, khususnya 
generasi muda bahkan dapat menimbulkan bahaya yang sangat besar bagi kehidupan dan nilai-nilai budaya bangsa yang pada akhirnya akan melemahkan ketahanan nasional. Narkoba dengan mudahnya dapat diperoleh bahkan sudah dapat diracik sendiri yang sulit dideteksi

Terutama juga juga karena narkoba yang dahulu diasumsikan sebagai barang eksklusif yang hanya bisa diperoleh di tempat-tempat gelap atau yang tadinya digunakan sebagai pelarian masalah, oleh anak-anak dari kalangan keluarga broken home atau hanya oleh golongan tertentu saja. Kini tidak bisa lagi dijadikan patokan atau dijadikan asumsi karena tidak seluruhnya benar, karena kenyataannya narkoba kini nyaris menyentuh semua elemen masyarakat bahkan banyak digunakan oleh anak-anak yang berasal dari keluarga harmonis, dan bukan hanya sebagai pelarian dari masalah yang sedang menghimpit kebahagiaan hati atau jiwanya, tetapi justru sebagai media rekreasi atau hiburan yang dianggapnya sebagai lambang kemajuan dalam pergaulan modern.

Hal tersebut, ternyata memang ada relevansinya dengan pengakuan seorang pengedar shabu-shabu, yang baru-baru ini berhasil di diamankan oleh aparat Negara, bahwa anak yang lugu, yang berasal dari keluarga harmonis atau keluarga baik-baik malah justru lebih mudah untuk dijadikan sasaran pengedar. Bahkan kini, anak anak yang memiliki intelektualitas memadai pun, bisa saja menjadi korban narkoba. Terbukti tidak sedikit dari kalangan mereka yang terkenal pandai, terpelajar atau berpendidikan tinggi banyak yang telah tergantung pada pemakaian obat-obat terlarang tersebut.

Maka, tidak mengherankan jika kesemarakan narkoba yang disertai dengan begitu banyaknya korban yang berjatuhan, tidak hanya akan menambah komplikasi keresahan serta ketakutan para oranga tua akan masa depan anak-anaknya. Tetapi juga semakin membentangkan kekhawatiran para tokoh masyarakat yang sangat peduli akan masa depan bangsa dan Negara. Mereka semuanya menjadi prihatin, dan cemas akan hilangnya generasi penerus bangsa yang berpotensial, berintegritasi, bermoral, beradab, beragama, dan berbudaya. Bila masalah ini tidak dapat segera diatasi dengan lebih intensif, maka 
masa depan generasi generasi mudah kita boleh berada di ujung tanduk sebab telah banyak bukti dan sulit bagi siapa pun untuk berkelit dari kenyataan tersebut.

Berdasarkan data-data yang dibeberkan oleh berbagai sumber pemerintah maupun LSM, masalah ketergantungan narkoba kini tidak lagi terjadi pada kalangan remaja atau dewasa muda, tetapi telah mulai mempengaruhi anak-anak di bawah umur.

Masalah yang akan dibahas pada kesempatan ini adalah bagaimana cara meencegah penyalah gunaan narkoba hususnya pada anak-anak di bawah umur.. Tujuan penulisan karya immiah ini adalah untuk memberikan penjelasan dan informasi kepada para pembaca tentang kapan narkoba mulai dikenal, bagaimana ragam dan klasifikasi narkoba, bagaimana perkembangan narkoba, bagaimana pandangan Islam tentang narkoba, serta bagaimana cara untuk mencegah penyalahgunaan narkoba.

Penyalahgunaan narkoba atau narkotik dan obat-obat terlarang di tanah air kita Indonesia, kini telah mencapai proporsi yang semakin meresahkan. Penyebaran narkoba tidak saja telah merata dan asarannya tidak hanya remaja dan dewasa muda di kota-kota besar, tetapi telah menyusup ke pelosok-pelosok desa. Bahkan yang lebih meresahkan karena mereka (para pecandu narkoba) telah banyak mempengaruhi anak-anak di bawah umur.

Merujuk data BNN pada 2018, prevalensi angka penyalahgunaan narkoba di kalangan pelajar di 13 ibu kota provinsi di Indonesia mencapai angkta 3,2 persen atau setara dengan 2,29 juta orang. Data di atas, menyatakan bahwa pemakai narkoba yang berusia di bawah umur menunjukkan angka yang sangat besar, maka dari itu pemahaman tentang bahaya narkoba perlu ditanamkan sedini mungkin.

Untuk itu, tidak mengherankan jika kesemarakan narkoba tidak hanya akan menambah komplikasi keresahan serta ketakutan para oranga tua akan masa depan anakanaknya. Tetapi juga semakin membentangkan kekhawatiran para tokoh masyarakat yang sangat peduli akan masa depan bangsa dan Negara. Mereka semuanya menjadi prihatin, dan 
cemas akan hilangnya generasi penerus bangsa yang berpotensial, berintegritasi, bermoral, beradab, beragama, dan berbudaya.

Adapun sumber data yang diambil penulis dalam rangka kepentingan karya tulis ilmiah ini diperoleh dari berbagai macam sumber referensi yang berkaitan dengan masalah diangkat dalam kesempatan kali ini sehingga terangkum seperti yang ada sekarang.

\section{B. Pembahasan}

\section{a. Kapankah Narkoba Mulai Dikenal?}

Narkoba atau narkotik dan obat-obat berbahaya, sebenarnya sejak dulu pun sudah ada. Tetapi pada akhir-akhir ini korban di Indonesia sudah semakin merambah ke semua lapisan masyarakat dan hal itu berbeda dengan siklus-siklus sebelumnya, misalnya bila dibandingkan dengan yang terjadi pada sekitar dekade 1970-1980an, dimana yang menjadi korban adalah lebih banyak dari kelompok remaja yang berasal dari kalangan rumah tangga berantakan (broken home).

Sedangkan kini, seperti yang telah disebutkan pada kata pendahuluan, anak-anak dari keluarga baik-baik pun sudah tidak aman lagi. Sebab sejak dari pertengahan dekade tahun 1990-an, penyebarannya semakin merata dan tidak pandang bulu dan pilih-pilih sasaran lagi. Sehingga yang menjadi korban pun banyak warga dari segala tingkat umur dan tingkat sosial, mulai dari anak-anak usia 11-12 tahun, sehingga manula, tidak peduli pula apakah dia seorang pembantu rumah tangga atau seorang pengusaha yang sukses, atau dari pengangguran sampai ke kalangan eksekutif muda. Dari kalangan selebriti, jetset maupun kalangan bawah yang sangat terbatas keuangannya. Semua telah terkena imbas narkoba tidak ada terkecuali atau terlewatkan!

Cara-cara yang dipakai untuk menjerat mangsa dari kelompok-kelompok yang bervariasi, itu pun semakin intensif dan canggih. Mulai dari cara-cara yang konvensional dengan membujuk korban untuk mencoba secara gratis, sampai menawarkannya dengan 
cara sebagai gaya hidup modern, terutama bila ditujukan kepada kaum muda remaja khususnya ABG (anak baru gede)

Bahkan narkoba sering kali dipromosikan sebagai terapi pelangsing tubuh atau sebagai obat untuk mengatasi lelah, penghilang stress dan sebagainya. Yang terkeji adalah membujuk anak-anak SD untuk mencoba obat-obat psikotropika yang berwujud permen atau coklat dengan iming-iming uang atau mainan.

Area penjualannya pun tidak terbatas pada tempat-tempat hiburan malam misalnya di nite club, discotik, dan sebagainya, tetapi sudah masuk ke daerah pemukiman, sekolah, sampai ke desa-desa yang terpencil. Kini sangat sulit untuk menemukan tempat tinggal atau kampus (universitas maupun sekolah (SMU), yang bebas narkoba, seperti yang sering diresahkan oleh para orang tua. Para tokoh masyarakat yang peduli akan masa depan anakanaknya, generasi harapan bangsa dan negaranya. Apabila mengingat jumlah korban yang ketagihan narkoba dari tahun ke tahun terus melonjak.

\section{b. Mengenal Ragam Narkoba}

Seperti yang telah disebutkan yang dimaksud narkoba adalah Narkotika yang sering pula disebut NAPZA, yakni Narkotik, Alkohol, psikotropika, dan zat adiktif yang semuanya merupakan kelompok obat-obatan yang berpengaruh tinggi/keras terhadap susunan saraf pusat (SSP), serta bisa menimbulkan banyak ketergantungan dalam jangka panjang.

Efek samping dari Narkoba juga bisa bermacam-macam, antara lain, mengurangi rasa sakit, membuat orang terstimulasi, atau menenangkan (mengantuk). Jadi yang termasuk dalam narkoba adalah :

- Narkotik;

- $\quad$ Obat-obat psikotropik;

- $\quad$ Halusinogenik (bersifat halusinogen);

- Inhalan; dan

- $\quad$ Zat adiktif. 
Yang paling tua dan yang paling berbahaya adalah kelompok narkotik yang dibagi dalam dua golongan, yakni:

a. Narkotik alami, dan

b. Narkotik semi semisintetik/sintetik.

\section{c. Perkembangan Narkotik}

Menurut hasil survey para pemerhati sampai tahun 2003, jumlah pengguna narkoba di Indonesia telah mencapai 2-3\% dari total penduduk dihitung dengan 200.000.000 (dua ratus juta) jiwa sehingga bila disimpulkan sedikitnya 4 sampai 6 juta jiwa yang telah terjerat narkoba. Khusus di Jakarta saja korban yang sudah tercatat oleh sebuah yayasan anti Narkotika, jumlahnya konon telah mencapai 1,5 juta jiwa, dan jumlah itupun masih akan terus betambah.

Dari data yang diungkapkan itu tentu saja akan menambah giris hati para tokoh masyarakat yang peduli sebab bukan karena jumlah itu dari Jakarta tetapi menurut para ahli, bila terdapat satu saja penyalahguna narkoba, maka berarti sedikitnya ada 10 (sepuluh) orang lainnya yang ikut terlibat/ terpengaruh. Jadi bila hal itu dibenarkan berarti junlah korban atau pecandu di Jakarta saja 1,5 juta x $10=15.000 .000$ orang. Bukan lagi satu koma lima juta tapi lima belas juta orang

Belum lagi kalau ditambah dengan yang ada di kota-kota besar lainnya, jumlahnya tentu akan lebih membuat bulu kuduk kita bediri, terlebih bila kita benar-benar turut menyelami betapa rumitnya persoalan narkoba, yang jelas tidak patut lagi kita diamkan saja, tanpa mau ikut peduli berpatisipasi didalam mencegah dan memberantas narkoba. Hingga permasalahan narkotik atau peredarannya yang sering kali menyulitkan para petugas atau siapa saja yang peduli untuk memberantasnya, menjadi semakin terkuak. Terlebih juga dengan tertangkapnya sebuah oknum dari kopassus, yang juga adalah puta seorang jendral yang waktu itu menjabat sebagai kepala staf Angkatan Darat yang tertuduh memilki 4 (empat) kilogram shabu-shabu dan 7000 butir pil ekstasi. 
Ditambah lagi dengan beberapa peristiwa lain yang mengungkap adanya anggotaanggota aparat keamanan dari berbagai kesatuan, yang seharusnya bertugas memberantas perdagangan narkoba, tetapi justru ikut bertindak sebagai penyalur; hal itu tentu saja menjadi sangat menggegerkan, bertambah meresahkan, bahkan membingungkan masyarakat luas.

Tidak heran bila kemudian muncul pula berbagai dugaan, bahwa peredaran narkoba di Indonesia, pasti telah didalangi oleh sindikat/mafia internasional. Sebab tidak tertutup kemungkinan, bahwa hal itu ada kaitannya dengan strategi global untuk mengawasi kawasan ASEAN; terutama Thailand, Malaysia dan Indonesia, melalui penghancuran moral masyarakat atau generasi muda yang hendak di jadikan sasarannya/pusat peredarannya.

Dugaan tersebut pun cukup beralasan, berdasarkan temuan-temuan baru, bahwa Indonesia bukan lagi sekedar sebagai Negara transit (tempat persinggahan) dalam perdagangan obat terlarang, tapi sudah menjadi target pasar, atau Negara sasaran bagi sindikat narkotik internasional. Dan dari pengakuan tersangka yang telah tertangkap, juga terungkap bahwa ternyata: Kokain dipasok oleh Cali,yakni sindikat narkotik dari Columbia. Heroin dan morfin dari Segitiga Emas (Golden Triangle) Asia, lewat Bangkok. Shabu-shabu dari daratan Cina, melalui Hongkong, Bangkok serta Singapura.

Hal itu jelas berarti bahwa kejahatan narkoba telah berubah sifatnya; dan bukan merupakan kejahatan kriminal belaka, tapi sudah menjadi kejahatan yang terorganisir dan secara sistematis diarahkan untuk menggerogoti sendi-sendi moral masyarakat/ generasi muda di seluruh dunia.

Dalam kerangka ini, kiranya masih cukup relevan pula jika kita kembali merenungi sebuah ungkapan Bung Karno, Presiden RI ke-1, bahwa:

"Untuk membina sebuah bangsa, dapat dimulai dengan membangun (moral) generasi mudanya sama halnya untuk menghancurkan sebuah bangsa, dapat dapat dimulai dengan menghancurkan (moral) generasi mudanya." 
Sebab, bukankah generasi muda adalah "tulang punggung" maju-mundurnya sebuah bangsa? Dan, bukankah generasi muda saat ini, juga merupakan tunas-tunas harapan, yang nantinya akan menggantikan para pemimpin Negara, yang sekarang tengah memerintah?

Untuk itu, kewaspadaan dan kehati-hatian di dalam membina dan membentuk moral generasi muda sangat diperlukan. Sebab jelas, kita tidak hanya memerlukan siklus situasi yang damai dan kondusif, tapi juga memerlukan pemahaman akan paradigma dan definisi yang tidak lagi feudal, sempit dan kuno. Karena nyaris setiap waktu,berbagai perubahan, baik di bidang teknologi informasi maupun dalam lingkup yang lebih luas serta konprehensif, selalu terjadi. Dan itu berarti, menuntut elastisitas dan akselerasi logika berpikir yang akurat dari masing-masing kita di dalam memahami pemahaman tersebut.

Apalagi kini, tak dapat dipungkiri lagi, bahwa narkoba memang bukan lagi barang ekslusif, yakni yang hanya bisa diperoleh di tempat-tempat tertentu, atau di tempat-tempat "gelap" narkoba yang tadinya hanya digunakan oleh golongan tertentu, kini nyaris telah menyentuh semua elemen masyarakat. Dari mulai artis, atlet, pengusaha, sampai anakjalanan sekalipun sudah mengenalnya. Bahkan beberapa tahun belakangan ini, segala macam obat-obatan terlarang itu, telah hadir pula di sekeliling masyarakat, diperumahan, dan semakin merambah sekolah-sekolah.

Seperti yang disebutkan oleh para pemerhati, bahwa "Di Jakarta kini tidak ada satu pun universitas atau SMU, yang bisa menyatakan diri bebas dari narkotika dan obat-obatan terlarang. Dengan kata lain, pasti sedikitnya ada satu atau dua, bahkan mungkin puluhan siswa di setiap sekolah/ universitasnya, pasti ada yang terlibat narkoba.

Sama juga dengan apa yang baru-baru ini di ungkapkan oleh Sekretaris Jendral PBB. Koffi Annan, bahwa "Narkoba sedang mencabik-cabik masyarakat kita, memicu aksi-aksi kejahatan, menyebarkan penyakit seperti AIDS, dan merenggut nyawa kaum muda serta masa depan kita."

Jika memang begitu maka jelaslah aparat keamanan sehebat apapun tidak akan dapat memberantasnya sendiri. Sebab memang tidak akan ada kekuatan yang bisa 
diandalkan kecuali dengan menggalang kerjasama dan mempersatukan kekuatan diantara kita.

\section{d. Pandangan Islam Mengenai Narkoba}

Obat terlarang sangat banyak macamnya dan beragam, sebagian lebih berbahaya adalah heroin yang dimasukkan dengan cara disuntikkan secara langsung ke dalam urat atau dengan cara dihirup dengan hidung. Satu tegukkan obat ini dapat mengalami kecanduan.

Juga benda-benda memungkinkan menjadi pengganti obat terlarang, seperti pelarut cat, bensin, dan getah. Benda-benda tersebut sangat memungkinkan untuk dijadikan pengganti obat terlarang, khususnya bagi orang yang tidak memiliki kemampuan untuk mendapatkan obat terlarang alami atau yang sudah diproduksi. Sedangkan hUkum islam mengenai obat terlarang ,

"Hai orang-orang beriman sesungguhnya (meminum) khamar, berjudi, (berkorban untuk berkhala, mengundi nasib dengan tanah), adalah perbuatan keji termasuk perbuatan setan. Maka jauhilah perbuatan-perbuatan itu agar kamu mendapat keberuntungan."

\section{(QS. Al-Maa'idah : 90)}

Nash dari ayat di atas sangat jelas mengharamkan minuman khamr dan tidak menyebutkan obat terlarang. Namun demikian, sunnah Rasul yang suci datang menafsirkan tentang khamr.

"'Setiap yang memabukkan adalah haram dan setiap yang memabukkan adalah khamr."

Hukum dari hadits tersebut berkaitan eret dengan terjadinya illah (keburukan) yang diakibatkannya. Illah pengharaman khamr adalah kemabukan dan segala sesuatu yang di dalamnya terdapat hal-hal yang memabukkan dan hilangnya akal sehat juga terdapat hukum pengharaman. Dengan demikian, maka obat terlarang yang kedudukannya sama dengan khamr dalam menghilangkan akal sehat para pecandunya, 
dimana dalam agama Islam dianggap sebagai sesuatu yang haram. Para ulama yang hidup di zaman yang di dalamnya terdapat penyakit semacam ini bersepakat mengharamkannya. Syaikul Islam rahimahullah berkata :

"Daun ganja yang dilaknat dan memabukkan lainnya dan segala sesuatu yang memabukkan menurut kesepakatan ulama adalah haram. Bahkan, segala sesuatu yang dapat menghilangkan akal sehat, haram untuk dimakan sekalipun sesuatu itu tidak memabukkan."'

Adapun illah pengharamannya adalah karena obat-obatan itu memabukkan seperti khamr. Hanya saja bila dihubungkan dengan khamr, obat terlarang ini dapat berakibat pada kelemahan dan kelesuan hingga pada saat merusak pembawaan orang yang melakukan transaksi atau bahkan menyebabkan kegilaan.

\section{e.Kiat Pencegahan}

Kiat untuk mencegah penyebarluasan penggunaan narkoba :

$>$ Seringlah mengadakan pertemuan atau diskusi untuk membicarakan masalah narkoba secara terbuka dengan anak-anak anda.

> Jangan tunggu sampai anak punya masalah, sebab rata-rata pasien yang datang ke klinik konsultasi ternyata telah menggunakan sedikitnya selama satu-dua tahun sebelum orang tua mengetahuinya.

$>$ Mulailah berbicara mengenai Narkotika dan zat adiktif sedini mungkin dan biarkan pintu komunikasi tetap terbuka.

$>$ Jangan takut kesulitan menjawab pertanyaan anak. Anda bisa memperoleh panduan dari artikel-artikel yang sering dimuat di dalam tabloid, koran, majalah, atau menghadiri setiap ada seminar.

$>$ Jadilah pendengar yang baik, pastikan bahwa anda telah menciptakan suasana nyaman, yang tidak menakutkan, sehingga anak atau korban akan merasa enak berbicara/mencurahkan segala isi hatinya. 
> Usahakan menjaga emosi, baik yang dilontarkan dengan kata-kata maupun yang dinyatakan dengan body language (bahasa tubuh) anda.

$>$ Sampaikan pesan secara jelas, berikan alasan yang bisa di terima, gunakan bahasa yang tegas, mudah dimengerti oleh anak, dan jangan memasukkan informasi yang tidak perlu.

$>$ Jangan menyela jika anak sedang berbicara mengungkapakan pendapat, terutama isi hatinya. apalagi mencela pendapat yang akan membuat anak akhirnya menjadi malas untuk berbicara.

> Berikan tanggapan anda setelah anak selesai berbicara, sebagai bukti bahwa anda bersungguh-sungguh mendengarkan segala penuturannya.

$>$ Jadilah orang tua panutan, yakni yang benar-benar saling menyayangi, memperhatikan dirinya dalam keadaan yang bagaimanapun buruk atau betapa besarpun kesalahan yang telah diperbuatnya.

> Pastikan bahwa anak anda juga telah berlaku jujur, terbuka, serta konsisten, yakni bertanggung jawab dengan apa yang telah anda kemukakan/ sampaikan.

Sebab, apapun yang telah terjadi anak adalah tetap anak, sejahat-jahatnya anak ia pasti akan merasa tunduk, luluh hatinya, apabila anda sebagai orang tua, dapat menunjukan sikap-sikap seperti di atas . Terutama adalah bila anda sebagai orang tua dapat selalu berlaku sabar agar membuahkan keberhasilan yang anda harapkan dalam mendidik anak anda yang merupakan generasi harapan bangsa.

\section{Kesimpulan}

Untuk mensosialisasikan bahaya Narkoba, mengingat struktur masyarakat Indonesia yang demikian kompleks dan heterogen dengan tingkat intelektual atau daya nalar yang beragam memang dibutuhkan sebuah program preventif tentang "drugs education" yang lebih baik dan terarah. Karena bagaimana pun, masyarakat atau lebih tepatnya lingkungan sekitar, mempunyai dampak/ peranan yang cukup signifikan di dalam mempengaruhi 
kebiasaan maupun karakter seseorang, terutama bagi seorang anak yang baru meningkat remaja, khususnya yang di sebut ABG (Anak Baru Gede).

Maka, selain edukasi (pendidikan) di dalam keluarga dan sekolah, edukasi di dalam masyarakat pun menjadi hal yang sentral dan menentukan. Dalam hal ini, edukasi masyarakat mencakup bagaimana sikap yang harus diambil seorang anggota masyarakat, dalam menghadapi korban-korban narkoba dan bantuan macam apa yang bisa di lakukan untuk memotivasi keluarga korban, supaya mereka bisa instrospeksi, merenung, dan berpikir dengan lebih baik serta juga terarah.

\section{Daftar Pustaka}

Al-Qur'an dan Terjemahan

Indrawan. 2001. Kiat Ampuh Menangkal Narkoba. Bandung: CV. PIONIR JAYA

Hasan,Adnan. 1998. Bahaya Obat terlarang terhadap Anak Kita. Jakarta : GEMA INSANI

H.MardaniPenyalahgunaan Narkoba Dalam Perspektif Hukum Islam Dan HukumPidana Nasional, (Jakarta, PT. Raja GrafindoPersada . Thn 2008 )

https://id.wikipedia.org/wiki/Narkoba diakses, 06 Agustus 2019

https://www.honestdocs.id/10-dampak-buruk-narkoba-bagi-kesehatan-manusia diakses 06 Agustus 2019

Kompas.com Penyalahgunaan dan Peredaran Narkotika Semakin Meningkat", https://nasional.kompas.com/read/2019/06/26/11421691/bnn-sebutpenyalahgunaan-dan-peredaran-narkotika-semakin-meningkat 